\title{
HUBUNGAN ANTARA KECERDASAN EMOSIONAL DENGAN KINERJA GURU \\ (Studi Pada Guru SDI Sabilil Huda Sumorame-Candi)
}

\author{
Drs. H. M. ZAINAL ABIDIN, M.Si \\ (Dosen Fakultas Psikologi Umsida) \\ ISWATUN NISAK
}

\begin{abstract}
Abstrak
Kecerdasan emosional merupakan kemampuan untuk mengenali perasaan, meraih dan membangkitkan perasaan untuk membantu pikiran, memahami perasaan dan maknanya, dan mengendalikan perasaan secara mendalam sehingga membantu perkembangan emosi dan intelektualnya.

Kinerja guru adalah kesanggupan dan kecakapan para guru dalam menciptakan suasana komunikasi yang edukatif antara guru dan peserta didik yang mencakup suasana kognitif, afektif dan psikomotorik sebagai upaya mempelajari sessuatu berdasarkan perencanaan sampai dengan tahap evaluasi dan tindak lanjut agar mencapai tujuan pengajaran.

Dalam penelitian ini bertujuan untuk mencari jawaban atas rumusan masalah "apakah ada hubungan antara kecerdasan emosional $(X)$ dengan kinerja pada $(Y)$ guru SDI Sabilil Huda Sumorame, Candi Kabupaten Sidoarjo?"

Jumlah populasi dalam penelitian ini 25 orang guru dan dengan taraf kesalahan $1 \%$ diperoleh sampel 24 orang guru dengan menggunakan teknik simple random sampling.

Data penelitian diambil dengan menggunakan skala Kecerdasan Emosional dan Skala Kinerja Guru. Metode analisis data yang digunakan adalah korelasi product moment dari Karl Pearrson. Hasil analisis data yang dilakukan menunjukkan adanya hubungan yang signifikan antara kecerdasan emosional dengan kinerja guru dengan koefisien korelasi 0,647. Nilai koefisien korelasi tersebut positif, yang artinya semakin tinggi kecerdasan emosional guru, maka semakin tinggi pula kinerja guru, dan sebaliknya semakin rendah kecerdasan emosional guru, maka semakin rendah pula kinerja guru.
\end{abstract}

Kata kunci : kecerdasan emosional, kinerja guru, guru.

\section{Latar Belakang}

Tenaga guru adalah salah satu tenaga kependidikan yang mempunyai peran sebagai faktor penentu keberhasilan tujuan suatu organisasi selain tenaga kependidikan lainnya, karena guru yang langsung bersinggungan dengan peserta didik untuk memberikan bimbingan yang muaranya akan menghasilkan tamatan yang diharapkan. Dalam UndangUndang No. 20/2003 (2003:3) mengenai sistem pendidikan nasional yang berdasarkan Pancasila dan Undang-Undang Dasar Negara
Republik Indonesia 1945, pendidikan nasional adalah pendidikan yang berakar pada nilai-nilai agama, kebudayaan nasional Indonesia, dan tanggap terhadap tuntutan perubahan zaman.

Berdasarkan tujuan pendidikan nasional ini sangat jelas peranan guru yang vital. Sebagai salah satu komponen dalam proses belajar mengajar (PBM), Syafruddin dan Basyiruddin (2002:7) menyatakan bahwa guru memiliki posisi yang sangat menentukan keberhasilan pembelajaran dalam merancang, 
mengelola, melaksanakan dan mengevaluasi pembelajaran. Ia juga memiliki kedudukan sebagai figur sentral dalam meningkatkan proses belajar mengajar. Di tangan para gurulah terletak berhasil tidaknya pencapaian tujuan belajar mengajar di sekolah, serta di tangan mereka pulalah bergantungnya masa depan karir peserta didik yang menjadi tumpuan para orang tua.

Berkaitan dengan itu, maka guru akan menjadi bahan pembicaraan banyak orang, dan tentunya tidak lain berkaitan dengan kinerja dan totalitas dedikasi dan loyalitas pengabdiannya. Kinerja guru merupaka elemen kunci dalma sistem pendidikan, khususnya di sekolah. Semua komponen lain, mulai dari kurikulum, saranaprasarana, baiaya, dan sebagainya tidak akan banyak berarti apabila esensi pembelajaran yaitu kinerja guru yang dituntut akan kualitasnya.

Guru bisa dikatakan memiliki kinerja berkualitas bilamana guru tersebut memiliki ketrampilan emosional yang merupakan bagian dari kecerdasan emosional. Ketrampilan emosional yang harus dimiliki guru diantaranya adalah interaksi guru dengan peserta didik, dimana interaksi guru dengan peserta didik akan dapat berkualitas jika interaksi antara guru dengan guru, guru dengan kepala sekolah dan guru dengan staf sekolah juga baik. Interaksi yang baik dengan orang lain akan baik jika mempunyai kecerdasan emosional yang baik pula. Goleman (2000:16) mengemukakan bahwa kecerdasan emosional menentukan posisi seseorang mempelajari ketrampilan-ketrampilan praktis yang didasarkan pada lima unsurnya, yaitu: kesadaran diri, motivasi diri, pengendalian diri, empati dan keterampilan dalam membina hubungan.

Dalam dunia pendidikan kinerja guru merupakan hasil yang dicapai guru dalam melaksanakan tugas-tugas yang didasarkan atas kecakapan, pengalaman dan kesungguhan serta penggunaan waktu di dalam proses belajar mengajar di sekolah. Menurut Direktur Tenaga Kependidikan PMPTK Surya Dharma (2008:20) Kinerja guru akan baik jika guru telah melaksanakan unsur-unsur yang terdiri dari kesetiaan dan komitmen yang tinggi pada tugas mengajar, menguasai dan mengembangkan bahan pelajaran, kedisiplinan dalam megnajar dan tugas lainnya, kreativitas dalam melaksanakan pengajaran, kerja sama dengan semua warga sekolah, kepemimpinan yang menjadi panutan siswa, kepribadian yang baik, jujur dan obyektif dalam membimbing siswa, serta tanggung jawabb terhadap tugasnya.

Kinerja guru dari hari kehari, minggu ke minggu dan tahun ke tahun akan terus ditingkatkan. Guru punya komitmen untuk terus dan terus belajar, tanpa itu maka guru akan kerdil dalam ilmu pengetahuan, akan tetap tertinggal akan akselerasi zaman yang semakin tidak menentu. Apalagi pada kondisi masa kini, kita dihadapkan pada era global, semua serba cepat, serba dinamis, dan serba kompetitif.

Begitu pentingnya peran guru dalam menstransformasikan inputinput pendidikan, sampai-sampai banyak pakar menyatakan bahwa di sekolah tidak akan ada perubahan atau peningkatan kualitas tanpa adanya perubahan dan peningkatan kualitas guru dalam hal kinerjanya.

Guru di mata masyarakat dan siswa merupakan panutan yang perlu 
dicontoh dan merupakan suri tauladan dalam kehidupannya sehari-hari. Selain adanya interaksi yang baik dengan murid atau siswa guru juga perlu memiliki ketrampilan sosial yang baik pula dengan masyarakat, dalam rangka pelaksanaan proses pembelajaran yang efektif. Dengan dimilikinya kemampuan tersebut, otomatis hubungan sekolah dengan masyarakat akan berjalan dengan lancar, sehingga jika ada keperluan dengan orang tua siswa, para guru tidak akan mendapat kesulitan. Jadi, bukan hanya hubungan guru dengan orang-orang yang ada di sekolah saja yang harus terjalin dengan baik, tetapi hubungan guru dengan masyarakat di luar sekolah termasuk orang tua murid juga harus terjalin dengan baik.

Namun, apabila kita melihat realitas yang terjadi ternyata kualitas guru pada saat ini masih banyak dibicarakan orang, atau masih saja dipertanyakan, baik dikalangan para pakar pendidikan maupun di luar pakar pendidikan.

Selama dasawarsa terakhir ini hampir tiap hari media massa baik harian maupun mingguan memuat berita tentang guru, ironisnya beritaberita tersebut banyak yang cenderung melecehkan posisi guru, baik yang sifatnya menyangkut kepentingan umum sampai kepada hal-hal yang sifatnya snagat pribadi, sedangkan dari pihak guru sendiri nyari tidak mampu membela diri.

Moh. Uzer (2006:3) menyatakan masyarakat kadangkadang mencemoohnya dan menuding guru tidak berkompeten, tidak berkualitas dan sebagainya, manakala putra-putrinya tidak bisa menyelesaikan persoalan yang ia hadapi sendiri atau memiliki kemampuan yang tidak sesuai dengan harapan orang tuanya. Sikap dan perilaku masyarakat tersebut memang bukan tanpa alasan, karena memang ada sebagian oknum guru yang menyimpang dari kode etiknya. Anehnya lagi kesalahan sekecil apapun yang diperbuat guru mengundang reaksi yang begitu hebat di masyarakat. Hal ini dapat dimaklumi karena dengan sikap yang demikian akan menunjukkan bahwa memang guru seyogyanya menjadi panutan bagi masyarakat di sekitarnya.

Istilah Emotional Intelegence diciptakan dan secara resmi didefinisikan oleh John Mayer Peter Salovey pada tahun 1990 dalam Steven J. dkk (2002:32). Sementara Reuven Bar-On menymbangkan ungkapan Emotional Intelegence atau kecerdasan emosi yang merupakan wacana baru di wilayah psikologi dan pedagogik setelah bertahun-tahun masyarakat sangat meyakini bahwa faktor penentu keberhasilan hidup seseorang adalah IQ.

Temuan penelitian di bidang psikologi yang dilakukan oleh Gardner tentang multiple intelegence menyatakan bahwa manusia memiliki banyak kecerdasan, yang bukan hanya kecerdasan intelektual saja telah membuka cakrawala baru tentang potensi manusia yang belum dieksplorasi untuk mendorong keberhasilan hidup. Penelitianpenelitian sekarang menemukan bahwa keterampilan sosial dan emosional ini mungkin bahkan lebih penting bagi keberhasilan hidup ketimbang kemampuan intelektual. Laurence (1998:4-6) menyatakan dengan kat alain, memiliki EQ tinggi mungkin lebih penting dalam pencapaian keberhasilan ketimbang IQ tinggi yang diukur berdasarkan uji standar terhadap kecerdasan kognitif verbal dan nonverbal. 
Sangat tertariknya banyak orang terhadap konsep kecerdasan emosional memang dimulai dari perannya dalam membesarkan dan mendidik anak-anak, tetapi selanjutnya orang menyadari pentingnya konsep ini baik di lapangan kerja maupun di hampir semua tempat lain yang mengharuskan manusia saling berhubungan, termasuk didalamnya adalah konsep kecerdasan emosional untuk kinerja guru.

Era reformasi dan desentralisasi pendidikan menyebabkan orang bebas melakukan kritik, titik lemah pendidikan akan menjadi bahan dan sasaran empuk bagi para kritikus, adakalanya kritik yang diberikan dapat menjadi sitawar sidingin di dalam memperbaiki kinerja guru. Akan tetapi tidak tertutup kemungkinan pula akan dapat membuat merah telinga guru sebagai akibat dari kritik yang diberikan, hal ini dapat memberikan dampak terhadap kinerja guru yang bersangkutan.

Apapun kritik yang diberikan, apakah bernilai positif atau negatif kiranya akan menjadi masukan yang sangat berarti bagi kinerja guru. Guru yang memiliki kecerdasan emosional yang baik tidak akan pernah putus asa, dan menjadikan kritikan sebagai pemicu baginya di dalam melakukan perbaikan dan pembenahan diri di masa yang akan datang. Kritik terhadpa kinerja guru perlu dilakukan, tanpa itu bagaimana guru mengetahui kinerja yang sudah dilakukannya selama ini, dengan demikian akan menjadi bahan renungan bagi guru untuk perbaikan kinerja lebih lanjut. Dalam menanggapi kritik-kritik tersebut maka seyogyanya seorang guru memiliki kecerdasan emosional supaya bisa menginterpretasikan kritikan tersebut dengan baik, sehingga menghasilkan output kinerja yang baik pula.

Bila kita amati di lapangan, bahwa guru sudah menunjukkan kinerja maksimal di dalam menjalankan tugas dan fungsinya sebagai pendidik, pengajar dan pelatih. Akan tetapi barangkali masih ada sebagian guru yang belum menunjukkan kinerja baik, tentunya secara langsung dipengaruhi oleh kecerdasan emosionalnya.

Kinerja guru akan menjadi optimal, bilamana diintegrasikan dengan komponen-komponen yang ada di sekolahan, apakah itu kepala sekolah, guru, karyawan maupun anak didik. Kinerja guru akan bermakna bila dibarengi dengan niat yang bersih dan ikhlas, serta selalu menyadari akan kekurangan yang ada pada dirinya, dan berupaya untuk dapat meningkatkan atas kekurangan tersebut sebagai upaya untuk meningkatkan kearah yang lebih baik. Kinerja yang dilakukan hari ini akan lebih baik dari kinerja hari kemarin, dan tentunya kinerja masa depan lebih baik dari kinerja hari ini.

\section{Landasan Teori}

\section{Kecerdasan Emosional (EQ)}

Robert dan Ayman (2002:14) mendefinisikan emosi sejak lama dianggap memiliki kedalaman dan kekuatan sehingga dalam bahasa latin misalnya, emosi dijelaskan sebagai motus anima yang berarti jiwa yang menggerakkan kita. Akar kata emosi adalah movere, kata kerja bahasa latin yang berarti menggerakkan, bergerak.

Menurut Goleman (2000:7) emosi mempunyai peran dalam peningkatan proses konstruksi pikiran dalam berbagai bentuk pengalaman kehidupan manusia. Salovey dan Mayers mendefinisikan emosi sebagai respon terorganisasi, termasuk sistem 
fisiologis, yang melewati bernagai batas sub-sistem psikologis, misalnya kognisi, motivasi, dan pengalaman. Pengertian ini menunjuukkan bahwa emosi merupakan respon atas stimulus yang diperoleh dari lingkungan sekitar yang terorganisasi dengan baik yang melewati sub-sistem psikologis (Tekad, 2001:37).

Crow dan Crow dalam Hartati (2004;90) menyebutkan bahwa emosi merupakan suatu keadaan yang bergejolak pada diri individu yang berfungsi sebagai inner adjusment terhadap lingkungan untuk $m$ encapai kesejahteraan dan keselamatan individu. Emosi pada definisi ini berperan dalam pengambilan keputusan yang menentukan kesejahteraan dan keselamatan individu.

Menurut Abdul Rachman dan Muhbib (2004:168) terdapat dua macam pendapat tentang terjadinya emosi yaitu pendapat navistik dan pendapat empiristik. Pendpat navistik beranggapan bahwa emosi pada dasarnya merupakan bawaan sejak lahir, sementara pendapat empiristik beranggapan bahwa emosi dibentuk oleh pengalaman dan proses belajar.

Sebagian orang menganggap bahwa perasaan dan emosi adalah sama. Namun, Sabri (2001:74) mengungkapkan bahwa antara perasaan dan emosi adalah berbeda. Pada perasaan terdapat kesediaan kontak dengan situasi luar (baik positif maupun negatif), sedangkan pada emosi kontak itu seolah-olah menjadi retak atau terputus (misalnya terkejut, ketakutan, mengantuk dan lain sebagainya).

Kecerdasan merupakan suatu kemampuan tertinggi dari jiwa makluk hidup yang hanya dimiliki oleh manusia. Kecerdasdan ini di peroleh manusia sejak lahir, dan sejak itulah potensi kecerdasan ini mulai berfungsi mempengaruhi tempo dan kualitas perkembangan individu, dan manakala sudah berkembang, maka fungsinya akan semakin berarti lagi bagi manusia yaitu akan mempengaruhi kualitas penyesuaian dirinya dengan lingkungannya.

Kemampuan kecerdasan dalam fungsinya yang disebutkan terakhir bukanlah kemampuan genetis yang dibawa sejak lahir, melainkan merupakan kemampuan hasil pembentukan atau perkembangan yang dicapai oleh individu.

Suharsono

menyebutkan bahwa kecerdasan adalah kemampuan untuk memecahkan masalah secara benar, yang secara relatif lebih cepat dibandingkan dengan usia biologisnya. Gardner dalam Rose (2002:58) mengemukakan bahwa kecerdasan adalah kemampuan untuk memecahkan masalah atau menciptakan suatu produk yang bernilai dalam suatu latar belakang budaya atau lebih.

Dari beberapa pengertian kecerdadsan yang telah dikemukakan maka dapat ditarik kesimpulan bahwa kecerdasan adalah kemampuan seseorang untuk memberikan solusi terbaik dalam penyelesaian masalah yang dihadapinya sesuai dengan kondisi ideal suatu kebenaran.

$$
\text { Gardner dalam Rose dan }
$$
Malcon (2002:59-60) membagi kecerdasan menjadi tujuh macam yaitu: kecerdasan linguistik, kecerdasan logis-mathematis, kecerdasan visual-spasial, kecerdasan musikal, kecerdasan kinestetik tubuh, kecerdasan interpersonal dan kecerdasan intrapersonal. Kecerdasankecerdasan tersebut dapat dijabarkan sebagai berikut: kecerdasan linguistik yaitu kemampuan membaca, menulis 
dan berkomunikasi dengan kata-kata atau bahasa. Kecerdasan logis matematis yaitu kemampuan berfikir (menalar) dan menghitung, berfikir logis dan sistematis. Kecerdasan visual-spasial kemampuan berfikir menggunakan gambar, memvisualisasikan hasil masa depan. Kecerdasan musikal yaitu kemampuan mengubah atau mencipta musik, dapat bernyanyi dengan baik atau memahami dan mengapresiasi musik serta mengerti ritme. Kecerdasan kinestetik-tubuh yaitu kemampuan menggunakan tubuh secara terampil untuk memecahkan masalah, menciptakan barang serta dapat mengemukakan gagasan dan emosi. Kecerdasan interpersonal yaitu kemampuan bekerja secara efektif dengan orang lain dan berempati. Kecerdasan intrapersonal yaitu kemampuan menganalisis diri sendiri, membuat rencana dan menyusun tujuan yang akan dicapai.

Kecerdasan yang dikemukakan Gardner ini dikenal juga sebagai multiple intelligence. Pembagian kecerdasan oleh Gardner ini telah membuka paradigma baru dari sebuah kata kecerdasan. Karena berdasarkan pembagian-pembagian kecerdasan menurutnya, ternyata cerdas bukan semata dapat memiliki skor tinggi sewaktu ujian, namun cerdas itu beraneka ragam.

Kecerdasan orang banyak ditentukan oleh struktur otak-otak besar yang dibagi dalam dua belahan otak yang disambung oleh segumpal serabut yang disebut corpus callosum. Belahan otak kanan menguasai belahan kiri badan dan sebaliknya belahan otak kiri menguasai belahan kanan badan.
Belahan otak kiri bertugas untuk merespon hal-hal yang sifatnya linier, logis dan teratur, sementara otak belahan kanan bertugas untuk imaginasi dan kreativitas (Conny, 2002:11-12).

Beberapa ahli mencoba merumuskan definisi dari kecerdasan emosional. Diantaranya Arief Rahman (2002:157-158) yang menyebbutkan bahwa kecerdasan emosional adalah metability yang menentukan seberapa baik manusia mampu menggunakan keterampilanketerampilan lain yang dimilikinya, termasuk intelektual yang belum terasah.

Bar-On seperti yang dikutip oleh Stein dan Book (2002:157158) mengemukakan bahwa kecerdasan emosional adalah serangkaian kemampuan, kompetensi dan kecakapan nonkognitif, yang mempengaruhi kemampuan seseorang untuk berhasil mengatasi tuntutan dan tekanan lingkungan.

$\begin{array}{rrr}\text { Dua } & \text { definisi } & \text { tentang } \\ \text { kecerdasan } & \text { emosional } & \text { yang }\end{array}$ dikemukakan oleh Rahman dan Bar-On lebih menekankan pada hasil yang didapat oleh individu jika menggunakan kemampuan secara optimal.

Salovery dan Mayer dikutip oleh Stein dan Book (2002:159) mengemukakan bahwa kecerdasan emosional adalah kemampuan untuk mengenali perasaan, meraih dan membangkitkan perasaan untuk membantu fikiran, memahami perasaan dan maknanya serta mengendalikan perasaan secara mendalam sehingga membantu perkembangan emosi dan intelektual. 
Goleman

dalam

Nggermanto (2002:29) mengatakan

bahwa kecerdasan emosional adalah kemampuan untuk mengenali perasaan kita sendiri dan perasaan orang lain, kemampuan memotivasi diri sendiri dan kemampuan mengelola emosi dengan baik pada diri sendiri dan dalam berhubungan dengan orang lain.

Dari beberapa definisi para ahli di atas dapat ditarik kesimpulan bahwa kecerdasan emosional adalah suatu kemampuan yang dimiliki oleh individu untuk dapat menggunakan perasaannya secara optimal guna mengenali dirinya sendiri dan lingkungan sekitarnya.

Kecerdasan emosional yang dimaksudkan oleh peneliti adalah kemampuan individu untuk mengenali perasaannya sehingga dapat mengatur dirinya sendiri dan menimbulkan motivasi dalam dirinya untuk meningkatkan kualitas hidupnya. Sementara di lingkungan sosial ia mampu berempati dan membina hubungan baik terhadap orang lain.

Kecerdasan emosional menurut Goleman (2002) adalah kemampuan guru untuk megenali emosi diri, mengelola emosi diri, memotivasi diri sendiri, mengenali emosi orang lain (empati), dan kemampuan untuk membina hubungan (kerja sama) dengan orang lain, yaitu meliputi 5 indikator sebagai berikut:

1. Empati

Merasakan yang dirasakan orang lain dan memahami perspektifnya, menumbuhkan hubungan saling percaya serta menyelaraskan diri dengan bermacam-macam orang.
2. Kesadaran diri

Mengetahui apa yang kita rasakan dan menggunakannya untuk memandu pengambilan keputusan diri sendiri serta memiliki tolok ukur yang realistis atas kemampuan dan kepercayaan diri yang kuat.

3. Pengaturan diri

Menangani emosi kita sehingga berdampak positif terhadap pelaksanaan tugas, peka terhadap kata hati dan sanggup menunda kenikmatan sebelum tercapainya suatu sasaran, mampu pulih kembali dari tekanan emosi.

4. Motivasi

Menggunakan hasrat untuk menggerakkan dan menuntun menuju sasaran, membantu mengambil inisiatif dan bertindak sangat efektif serta bertahan menghadapi kegagalan dan frustasi.

5. Keterampilan sosial

Menangani emosi dengan baik ketika berhubungan dengan orang lain dan dengan cermat membaca situasi dan jaringan sosial dan berinteraksi dengan lancar serta menggunakan keterampilan ini untuk mempengaruhi orang lain.

Senada dengan pendapat di atas, Shapiro (2001:5) juga menyebutkan kualitas-kualitas kecerdasan emosional, diantaranya: empati, mengungkapkan dan memahami mengendalikan perasaan, kemandirian, kemampuan menyesuaikan diri, disukai, kemampuan memecahkan masalah antarpribadi, ketekunan, kesetiakawanan, keramahan, dan sikap hormat. 
Ketika berbicara mengenai urgensitas kecerdasan emosional yang dimiliki seseorang dalam kehidupan, Suharsono (2004:97) mengungkapkan beberapa keuntungan kecerdasan emosional sebagai berikut: 1). Kecerdasan emosional jelas mampu menjadi alat untuk pengendalian diri, sehingga seseorang tidak terjerumus ke dalam tindakantindakan bodoh yang merugikan dirinya sendiri maupun orang lain. 2) Kecerdasan emosional bisa diimplementasikan sebagai cara yang sangat baik untuk memasarkan atau membesarkan ide, konsep atau bahkan sebuah produk. 3). Kecerdasan emosional adalah modal penting bagi seseorang untuk mengembangkan bakat kepemimpinan dalam bidang apapun. Karena setiap model kepemimpinan sesungguhnya membutuhkan visi, misi, konsep, program dan yang tak kalah pentingnya adalah dukungan dan partisipasi dari para anggota.

\section{Kinerja Guru}

Banyak batasan yang diberikan para ahli mengenai istilah kinerja. Wilayahnya pun berbeda dalam tekanan rumusannya, namun secara prinsip tampaknya sejalan mengenai proses pencapaian hasil. Istilah kinerja berasal dari kata job performance atau actual performance (prestasi kerja atau prestasi sesungguhnya yang dicapai seseorang). Sehingga dapat didefinisikan bahwa kinerja adalah hasil kerja secara kualitas dan kuantitas yang dicapai seorang pegawai dalam melaksanakan tugasnya sesuai dengan tanggungjawab yang diberikan kepadanya. (Anwar Prabu, 2004:67).

Hadari Nawawi (1996:34) mengartikan kinerja sebagai prestasi seseorang dalam suatu bidang atau keahlian tertentu, dalam melaksanakan tugasnya atau pekerjaannya yang didelegasikan dari atasan dengan efektif dan efisien. Lebih lanjut beliau mengungkapkan bahwa kinerja adalah kemampuan yang dimiliki individu dalam melakukan sesuatu pekerjaan, sehingga terlihat sesuatu pekerjaan, sehingga terlihat prestasi pekerjananya dalam mencapai tujuan.

Sedangkan menurut Ginson, Ivan Cevich dan Donelly (1993:28) bahwa kinerja sebagai prestasi kerja dari perilaku. Prestasi kerja itu ditentukan oleh kemampuan bekerja, baik terhadap cakupan kerja maupun kualitas kerja secara menyeluruh.

Guru yang dimaksud adalah orang yang pekerjaannya sebagai pengajar di sekolah. Menurut Moh. Uzer (2006:16) tugas guru dapat dikelompokkan menjadi tiga jenis yaitu: 1. Tugas dalam bidang profesi, guru merupakan suatu profesi yang memerlukan kehalian khusus, jenis pekerjaan ini tidak dapat dilakukan oleh orang yang tidak memiliki kapabilitas di bidang pendidikan. Tugas guru sebagai profesi meliputi aspek mendidik yaitu merumuskan dan mengembangkan nilai-nilai hidup, mengajar berarti meneruskan dan mengembangkan keterampilan kepada sisw,a dan melatih. 2. Tugas kemanusiaan. Tugas guru dalam bidang kemanusiaan adalah menjadikan dirinya sebagai orang tua kedua dari siswa. Ia harus mampu menarik simpati sehingga 
dapat menjadi panutan para siswanya. Pelajaran apapun yang diberikannya hendaknya dapat dijadikan motivasi bagi siswa dalam belajar. Bila seorang guru dalam penampilannya sudah tidak menarik, maka kegagalan pertama adalah ia tidak dapat menanamkan benih pengajarannya itu kepada para siswa. 3. Tugas dalam bidang kemasyarakatan. Masyarakat menempatkan guru pada tempat yang lebih terhormat di lingkungannya, karena dari seorang guru diharapkan masyarakat dapat memperoleh ilmu pengetahuan. Ini berarti bahwa guru berkewajiban mencerdasakan bangsa menuju kepada pembentukan manusia seutuhnya.

\begin{tabular}{llr}
\multicolumn{1}{c}{ Tugas } & guru & sebagai \\
pendidik & dan & pengajar \\
dimaksudkan & untuk & membantu
\end{tabular} orang tua dalam memenuhi kebutuhan untuk memberi bekal pada anak-anak agar memperoelh kehidupan yang layak setelah mencapai kedewasaannya kelak.

Kemudian guru seharusnya dapat menjalankan fungsinya, diantaranya adalah mengajar (teaching) yaitu memindahkan ilmu pengetahuan, pelatihan (training) yaitu membimbing keterampilan tertentu dan coaching yaitu memberdayakan potensi individu dari masing-masing siswa yang menjadi anak didiknya.

Dari uraian guru di atas dapat dilanjutkan dengan pembahasan tentang kinerja guru. Karena guru bergerak di bidang pendidikan dan pengajaran, maka tujuan yang ingin dicapai adalah tujuan dari pendidikan dan pengajaran tersebut.

Dengan demikian kinerja guru dapat dilihat dari perbuatan atau kegiatan belajar mengajar di dalam kelas, seperti yang dikemukakan oleh Aldag dan Stearns (1987:77), kinerja adalah seperti pengambilan keputusan pada waktu mengajar di kelas.

Menurut Suryo Subroto (1997:3) yang dimaksud dengan kinerja guru adalah kesanggupan atau kecakapan para guru dalam menciptakan suasnaa komunikasi yang edukatif antara guru dan peserta didik yang mencakup suasana kognitif, afektif dan psikomotorik sebagai upaya mempelajari sesuatu berdasarkan perencanaan sampai dengan tahap evaluasi dan tindak lanjut agar mencapai tujuan pengajaran.

Kinerja guru juga dapat diartikan sebagai prestasi kerja untuk meraih prestasi antara lain ditentukan oleh kemampuan dan usaha. Prestasi kerja guru dapat dilihat dari seberapa jauh guru tersebut telah menyelesaikan tugasnya dalam mengajar dibandingkan dengan standarstandar pekerjaan. Kemudian kinerja guru dapat diartikan pula sebagai suatu pencapaian tujuan dari guru itu sendiri maupun tujuan pendidikan dan pengajaran dari sekolah di tempat guru tersebut mengajar.

Menurut Direktur Tenaga Kependidikan Surya Dharma (2008:20) bahwa kinerja guru adalah keberhasilan guru dalam melaksanakan kegiatan belajar mengajar yang bermutu, meliputi aspek kesetiaan dan komitmen yang tinggi pada tugas mengajar, menguasai dan mengembangkan metode, menguasai bahan pengajaran dan menggunakan sumber belajar, bertanggung jawab memantau hasil belajar mengajar, 
kedisiplinan dalam mengajar dan tugas lainnya, kreativitas dalam melaksanakan pengajarna, melakukan interaksi dengan murid untuk menimbulkan motivasi, kepribadian yang baik, jujur dan obyektif dalam membimbing siswa, mampu berfikir sistematis tentang apa yang dilakukannya, dan pemahaman dalam administrasi pengajaran.

Payaman J. Simanjuntak (2005:10-13) dalam bukunya Manajemen dan Evaluasi Kinerja menyebutkan bahwa kinerja setiap orang dipengaruhi oleh banyak faktor, diantaranya sebagai berikut:

1) Kompetensi Individu

adalah kompetensi individu keterampilan melakukan kerja. Kompetensi setiap orang dipengaruhi oleh beberapa yang dapat dikelompokkan dalam dua golongan, yaitu: pertama, kemampuan dan ketrampilan kerja. Kedua, motivasi dan etos kerja.

Secara psikologis, kemampuan (ability) pegawai terdiri dari kemampuan potensi (IQ) dan kemampuan reality (knowledge + skill). Artinya pegawai yang memiliki IQ di atas rata-rata (IQ 110-120) dengan pendidikan yang memadai untuk jawabannya dan terampil dalam mengerjakan pekerjaan seharihari maka ia akan lebih mudah mencapai kinerja yang diharapkan.

Pendidikan dan pelatihan merupakan bagian dari intervensi sumber daya manusia (human investment). Semakin lama waktu yang digunakan seseorang untuk pendidikan dan pelatihan, semakin tinggi kemampuan atau kompetensinya melakukan pekerjaan, dan dengan demikian semakin tinggi kinerjanya. Sedangkan motivasi terbentuk dari sikap (attitude) seorang pegawai dalam menghadapi situasi kerja. Motivasi merupakan kondisi yang menggerakkan kondisi pegawai yang terarah untuk mencapai tujuan organisasi (tujuan kerja).

Motivasi dan etos kerja sangat penting untuk mendorong semangat kerja. Motivasi dan etos kerja dipengaruhi oleh latar belakang keluarga, lingkungan masyarakat, budaya dan nilainilai agama yang dianutnya.

Seseorang yang melihat pekerjaan sebagai beban dan keterapaksaan untuk memperoleh uang, akan mempunyai kerja yang rendah, sebaliknya, seseorang yang memandang pekerjaan sebagai kebutuhan pengabdian, tantangan dan prestasi, akan menghasilkan kinerja yang tinggi.

David C. Mc Clelland dalam Mangkunegara (2004:67) berpendapat bahwa ada hubungan yang positif antara motivasi berprestasi dengan pencapaian kinerja. Menurutnya ada enam karakteristik dari pegawai yang memiliki motivasi berprestasi yang tinggi: pertama, memiliki tanggung jawab pribadi yang tinggi,. Kedua, berani mengambil resiko. Ketiga, memiliki tujuan yang realistis. Keempat, memiliki rencana 
kerja yang menyeluruh dan berjuang untuk merealisasikannya. Kelima, memanfaatkan umpan balik (feed back) yang konkret dalam seluruh kegiatan kerja yang dilakukannya. Keenam, mencari kesempatan untuk merealisasikan rencana yang lebih diprogramkan.

2) Dukungan organisasi

Kinerja setiap orang juga tergantung pada dukungan organisasi dalam bentuk pengorganissian, penyediaan sarana dan prasarana kerja, pemilihan teknologi, kenyamanan lingkungan kerja, serta kondisi dan syarat kerja.

3) Dukungan manajemen

Kinerja setiap orang
sangat tergantung pada kemampuan manajerial para manajemen atau pimpinan, baik dengan membangun sistem kerja dan hubungan industrial yang aman dan harmonis, maupun dengan mengembangkan kompetensi pekerja, demikian juga dengan menumbuhkan motivasi dan memobilisasi pegawai untuk bekerja secara optimal.

\section{Hubungan antara Kecerdasan Emosional dengan Kinerja Guru \\ Dalam melaksanakan} tugasnya membentuk lulusan berkompetensi hendaknya guru memiliki kecerdasan emosional (EI) yaitu merupakan suatu kemampuan yang dimiliki oleh individu untuk dapat menggunakan perasaannya secara optimal guna mengenali dirinya sendiri dan lingkungan sekitarnya. Dengan kecerdasan emosional (EI) ini guru akan mampu melakukan praktekpraktek secara berkeunggulan yang bermuara pada kinerja guru.

Tingkat kecerdasan emosional seorang guru tinggi apagila ia mampu mengelola emosinya dan mampu memotivasi dirinya sendiri. Jika kecerdasan emosional dikaitkan dengan kinerja maka guru dengan kecerdasan emosional tinggi akan lebih mampu mengatasi kesulitan-kesulitan dalam melaksanakan tugastugasnya sehingga kinerjanya akan meningkat.

Jadi seorang guru yang memiliki kecerdasan emosional yang tinggi maka ia mempunyai kinerja yang tinggi pula. Sedangkan seseorang guru mempunyai kecerdasan emosional yang rendah maka dalam kinerjanya akan rendah pula. Sehingga hubungan antara kecerdasan emosional dengan kinerja guru dalam penelitian ini adalah keberhasilan seorang guru dalam melaksanakan kegiatan belajar megnajar yang bermutu, yang terbangun dari kecerdasan emosional guru tersebut.

\section{Analisa Data}

\section{Skala Kinerja Guru}

Dari analisis Validitas Item Skala Kinerja Guru diperoleh hasil sebagai berikut:

a. Item yang gugur/tidak valid sebanyak 10 terdiri dari item nomor

$17,21,25,26,32,33,34,35,36$ dan 39.

b. Item yang valid sebanyak 30 terdiri dari item nomor $1,2,3,4,5,6,7,8,9,10,11,12,13$, $15,16,18,19,20,22,23,24,27,28,29$, $30,31,34,37,38$ dan 40 . 
Kesimpulan item yang valid ataupun tidak valid pada skala Kinerja Guru ini didasarkan pada pendapat dari Azwar (1999:65) bahwa nilai minimal koefisien korelasi adalah 0,25 , sehingga di atas 0,25 dinyatakan Valid.

Adapun rincian validitas dari skala Kecerdasan Emosional adalah sebagai berikut:

\section{Rincian Kesahihan skala Kinerja Guru}

Dari item yang valid sebanyak 30 item, kemudian dihitung Reliabilitas Skala Kinerja Guru yang diperoleh hasil sebagai berikut: $\mathrm{N}$ subyek $=24, \mathrm{~N}$ item $=30$, Alpha Cronbachs $=0,890$. Menurut Azwar (1999:96) bahwa reliabilitas di atas 0,8 adalah baik, maka dapat dinyatakan bahwa skala Kinerja Guru adalah Reliabel.

Dari hasil data uji coba skala kecerdasan emosional dan kinerja guru ini, penulis menggunakan data try out terpakai yaitu menyebarkan angket atau kuesioner sekali saja karena adanya keterbatasan waktu, sehingga hasil data uji coba skala dalam penelitian ini bisa langsung dilanjutkan pada analisis data.

\section{Uji Asumsi Normalitas Sebaran}

Untuk menguji Normalitas Skala Kinerja Guru digunakan Teknik Kolmogorov-Smirnov. Hasil yang diperoleh bahwa skala Kinerja Guru dinytakan NORMAL, karena hasil dari perhitungan menggunakan program SPSS 16.00 for windows tampak nilai $\mathrm{p}$ (probability value/critical value) $=0,057$ lebih besar dari pada tingkat $\alpha$ yang digunakan yaitu $0,05(\mathrm{p}=0,057>\alpha=$ $0,05)$.

\section{Uji Asumsi Linearitas}

\section{Hubungan}

Berdasarkan hasil korelasi antara Variabel Kecerdasan Emosional dengan Kinerja Guru menggunakan program SPSS 16.00 for windows dengan teknik Analisis of Varians diperoleh $\mathrm{F}=72,719$ dengan $\mathrm{p}=0,000$, karena signifikansinya $<\alpha=0,05$, maka dapat disimpulkan bahwa antara variabel Kecerdasan Emosional dengan Kinerja Guru terdapat hubungan yang Linear.

\section{Hasil Uji Signifikansi dengan} Korelasi Product Moment Pearson

Berdasarkan hasil analisis korelasi, diperoleh $\mathrm{r}$ hitung variabel Kecerdasan Emosional dengan Kinerja Guru sebesar 0,647, sedangkan $r$ tabel sebesar 0,404, sehingga dapat disimpulkan bahwa $\mathrm{r}$ hitung $>\mathrm{r}$ tabel, dengan $\mathrm{p}<\alpha=0.05$ ( $\mathrm{p}=0.001)$. ini berarti ada hubungan yang signifikan antara Kecerdasan Emosional dengan Kinerja Guru. Semakin tinggi Kecerdasan Emosional diikuti dengan semakin tinggi Kinerja Guru.

Analisis korelasi dapat dilanjutkan dengan menghitung koefisien determinasi, dengan cara mengkuadratkan koefisien yang ditemukan. Jadi koefisien determinasinya adalah $0,647^{2}=0,419$. Hal ini bisa diartikan pengaruh kecerdasan emosional $=41,9 \%$, dan sisanya $58,1 \%$ ditentukan oleh faktor lain, seperti kompetensi guru (IQ guru), dukungan organisasi dan dukungan manajemen.

\section{Hasil Penelitian dan Diskusi Hasil Penelitian}

Kinerja guru atau prestasi kerja guru adalah hasil yang dicapai oleh guru dalam melaksanakan tugas-tugas yang diembankan kepadanya berdasarkan atas kecakapan, pengalaman dan kesungguhan serta waktu dengan output yang dihasilkan 
tercermin baik kuantitas maupun kualitasnya.

Dalam melaksanakan tugasnya membentuk lulusan berkompetensi hendaknya guru memiliki kecerdasan emosional (EI) yaitu merupakan suatu kemampuan yang dimiliki oleh individu untuk dapat menggunakan perasaannya secara optimal guna mengenali dirinya sendiri dan lingkungan sekitarnya. Dengan kecerdasan emosional ini guru akan mampu melakukan praktik-praktik secara berkeunggulan.

Tingkat kecerdasan emosional seorang guru tinggi apabila ia mampu mengelola emosinya dan mampu memotivasi dirinya sendiri. Jika kecerdasan emosional dikaitkan dengan kinerja maka guru dengan kecerdasan emosional tinggi akan lebih mampu mengatasi kesulitankesulitan dalam melaksanakan tugastugasnya sehingga kinerjanya akan meningkat.

Jadi seorang guru yang memiliki kecerdasan emosional yang tinggi maka ia mempunyai kinerja yang tinggi pula. Sedangkan seorang guru mempunyai kecerdasan emosional yang rendah maka dalam kinerjanya akan rendah pula. Dengan demikian diduga terdapat hubungan positif antara kecerdasan emosional dengan kinerja guru SDI SABILIL HUDA Sumorame Candi Sidoarjo.

Hasil penelitian ini membuktikan bahwa ada hubungan yang signifikan antara kecerdasan emosional dengan kinerja guru. Melalui penelitian dengan menggunakan teknik kuesioner yang berbentuk skala Likert pada kedua variabel penelitian yang disebarkan pada subyek penelitian yaitu guru SDI Sabilil Huda Sumorame Candi diperoleh hasil berupa data ordinal yang kemudian melalui proses tabulating dengan komputer program SPSS 16.00 for windows untuk melakukan analisis data dan pada uji validitas skala Kecerdasan Emosional. Dari item yang terdiri dari 40 butir pernyataan, diperoleh 13 item yang tidak valid/gugur $(4,5,16,19,23,24,27,29,30,33,34,35$ dan 36) dan 27 item ynag valid $1,2,3,5,6,8,9,10,11,12,13,14,15,17,18$, $20,21,22,25,26,28,31,32, \quad 33,37,38,39$ dan 40).

Kemudian pada uji validitas skala Kinerja Guru dari item yang terdiri dari 40 butir pernyataan, diperoleh 10 item yang tidak valid/gugur

$(17,21,25,26,32,33,34,35,36$ dan 39) dan 30 item yang valid $(1,2,3,4,5,6,7,8,9,10,11,12,13,15,16,18$ $, 19,20,22,23,24,27$, $28,29,30,31,34,37,38$ dan 40).

Dengan menggunakan uji coba (try out) terpakai, yaitu dengan menyebarkan angket/kuesioner satu kali saja, sehingga setelah dilakukan uji validitas pada kedua skala maka langsung dilanjutkan pada uji reliabilitas skala.

Hasil uji reliabilitas skala kecerdasan emosional dan skala kinerja guru diperoleh hasil bahwa skala kecerdasan emosional dan skala kinerja guru adlaah reliabel.

Setelah uji instrumen dilakukan, maka peneliti melanjutkan dengan uji asumsi pada kedua skala, yaitu uji normalitas pada skala Kinerja Guru dengan teknik KolmogorovSmirnov, memperoleh hasil bahwa skala Kinerja Guru memiliki sebaran data yang Normal. Dan uji asumsi Linearitas dengan teknik ANOVA (Analisis of Varians) pada skala Kecerdasan Emosional terhadap Kinerja guru dengan hasil bahwa Kecerdasan Emosional terhadap 
Kinerja Guru memiliki hubungan yang Linear.

Setelah uji asumsi dilakukan, peneliti melanjutkan dengan uji signifikan dengan rumus Korelasi Product Moment dari Pearson, dan memperoleh hasil bahwa terdapat hubungan yang signifikan antara Kecerdasan Emosional dengan Kinerja Guru dengan nilai koefisien korelasi sebesar 0,647.

Dan dari nilai koefisien korelasi yang didapat dilanjutkan dengan menghitung koefisien determinasi, dengan cara mengkuadratkan koefisien yang ditemukan. Jadi koefisien determinasinya adalah $0,647^{2}=0,419$. Hal ini bisa diartikan pengaruh kecerdasan emosional $=41,9 \%$, dan sisanya $58,1 \%$ ditentukan oleh faktor lain, seperti kompetensi guru (IQ guru), dukungan organisasi dan dukungan manajemen.

\section{Simpulan}

Berdasarkan hasil analisis dan interpretasi data penelitian dapat ditarik kesimpulan mengenai hasil penelitian, bahwa ada hubungan yang signifikan antara Kecerdasan Emosional dengan Kinerja Guru. Semakin tinggi Kecerdasan Emosional diikuti dengan semakin tinggi Kinerja Guru. Guru yang memiliki kecerdasan emosional yang tinggi maka kinerja guru tersebut pun akan tinggi pula. Sebaliknya semakin rendah kecerdasan emosional guru, maka semakin rendah pula kinerjanya.

$$
\text { Dan dari nilai koefisien }
$$

korelasi yang didapat dilanjutkan dengan menghitung koefisien determinasi, dengan cara mengkuadratkan koefisien yang ditemukan untuk mengetahui seberapa besar variabel kecerdasan emosional mempengaruhi varibael kinerja guru dan ditemukan bahwa selain kecerdasan emosional ternyata kinerja guru juga dipengaruhi oleh faktor lain seperti kompetensi guru, dukungan organisasi dan dukungan manajemen.

\section{Saran}

Dari penelitian yang telah dilakukan dan kesimpulan yang telah dikemukakan, maka peneliti memberikan beberapa saran pada pihak-pihak yang terkait. Saran-saran ini diharapkan dapat berguna bagi perkembangan kelanjutan studi ilmiah mengenai hubungan kecerdasan emosional dengan kinerja guru, berguna bagi mahasiswa kependidikan dan guru, serta bagi para pembaca penelitian ini.

1. Saran untuk peneliti selanjutnya Bagi peneliti selanjutnya yang ingin meneliti dengan tema penelitian yang sama atau hampir sama, bisa meneliti dengan mengambil sampel yang lebih heterogen dengan jumlah sampel yang lebih banyak supaya bisa lebih memperkaya hasil analisis datanya.

2. Saran untuk kalangan guru dan mahasiswa kependidikan sebagai calon guru.

Bagi para guru yang sudah lama ataupun yang masih baru mendedikasikan potensinya tersebut untuk mendidik dan membina tunas bangsa, jadikanlah hasil penelitian ini sebagai sesuatu yang bisa membangun kepribadian menjadi guru yang tidak hanya profesional bagi anak didiknya tetapi juga profesional bagi dirinya dengan memiliki kecerdasan emosional yang baik untuk menghasilkan tunas bangsa yang berkualitas dari segi kognisi dan juga emosionalnya. 
Dan bagi para calon-calon guru yang masih dalam proses pendidikan sebagai guru agar bisa menjadi bahan masukan yang berguna untuk kemajuan diri dan negara.

3. Saran untuk semua pembaca Diharapkan hasil penelitian ini sedikit banyak bisa bermanfaat untuk menambah ilmu dan wawasan pembaca tentang pentingnya kecerdasan emosional terhadap kinerja.

\section{Daftar Pustaka}

Anwar, Saifuddin. 1999. Penyusunan Skala Psikologi. Yogyakarta: Pustaka Pelajar.

Arikunto, Suharsimi. 2003. Dasardasar Evaluasi Pendidikan. Jakarta: Bumi Aksara. Cet. Ke4.

Azwar, Saifudin. 2009. Reliabilitas dan Validitas. Liberty. Yogyakarta: Pustaka Pelajar.

Cooper, Robert K. dan Ayman Sawaf. 2002. Executive EQ, Penerjemah Alex Tri Kantjono Widodo, Jakarta: Gramedia Pustaka Utama.

Dharma, Surya. 2008. Penilaian Kinerja Guru. Jakarta: Direktorat Tenaga Kependidikan Direktorat Jenderal Peningkatan Mutu Pendidik dan Tenaga Kependidikan Departemen Pendidikan Nasional.

Goleman, Daniel. 2000. Emotional Intelligence. Jakarta: Gramedia Pustaka Utama. Cet. Ke-10.
Hartati, Netty., et.all. 2004. Islam dan Psikologi. Jakarta: Raja Grafindo Persada.

Mangkunegara, Anwar Prabu A.A. 2004. Manajemen Sumber Daya Manusia Perusahaan. Bandung: Rosdakarya.

Munandir. 2001. Psikologi Pendidikan. Malang: UM Press.

Nggermanto, Agus. 2002. Quantum Quotient. Bandung: Nuansa.

Nurdin, Syafruddin dan M. Basyiruddin Usman. 2002. Guru Profesional dan Implementasi Kurikulum. Jakarta: Ciputat Press.

Rose, Colin dan Malcom J. Nicholl. 2002. Cara Belajar Cepat Abad XXI, penerjemah Dedy Ahimsa. Bandung: Nuansa.

Sabri, Alisuf M. 2001. Pengantar Psikologi Umum dan Perkembangan. Jakarta: Pedoman Ilmu Jaya.

Sambas Ali Muhidin dan Maman Abdurahman. 2009. Analisis Korelasi, Regresi, dan Jalur Dalam Penelitian. Bandung: CV. Pustaka Setia.

Segal, Jeanne. 2000. Melejitkan Kepekaan Emosional, penerjemah Ary Nilandari. Bandung: Kaifa.

Setiawan, Conny R. 2002. Belajar dan Pembelajaran dalam Taraf Pendidikan Usia Dini. Jakarta: Prenhallindo. 
Shaleh, Abdul Rahman dan Muhbib Abdul Wahab. 2004. Psikologi Suatu Pengantar dalam Perspektif Islam, Jakarta: Kencana.

Shapiro, Lawrence E. 2001. Mengajarkan Emotional Intelligence pada Anak, penerjemah Alex Tri Kantjono, Jakarta: Gramedia.

Simanjuntak, J. Payaman. 2005. Manajemen dan Evaluasi Kinerja. Jakarta: LPEE UI.

Stein, Steven J. dan Howard E. Book. M. D,. 2002. Ledakan EQ. Penerjemah Trinando Rainy Januarsari dan Yudhi Murtanto. Bandung: Kaifa.

Stiadi, Aryaguna A. V. 2001. Hubungan Antara Kecerdasan Emosional dengan
Keberhasilan Bermain Game. Indonesian Psychological Game Journal. Vol. 17 No. 1: 44-45.

Sugiono. 2003. Metode Penelitian Administratif. Bandung: Alfabeta.

Sugiyono. 2010. Metode Penelitian Kuantitatif, Kualitatif dan $R \& D$, Bandung: Alfabeta.

Usman, Moh. Uzer. 2006. Menjadi Guru Profesional. Bandung: PT. Remaja Rosdakarya.

UUSPN. 2003. Undang-Undang Republik Indonesia. Bandung: Citra Umbara. Hlm. 3.

Wayono, Tekad. 2001. Memahami Kecerdasan Emosi Melalui Kerja Sistem Limbik. Surabaya. 